\title{
Biodiversity of Sierra del Cristal, Cuba: first insights
}

\author{
J. E. Fa, J. P. Soy, R. Capote, M. Martínez, I. Fernández, A. Avila, D. Rodríguez, A. Rodríguez, F. Cejas \\ and G. Brull
}

\begin{abstract}
Cuba has the highest combined animal and plant diversity, and the highest degree of endemism, in the West Indies. In 1998 we undertook the first major biodiversity survey of the Sierra del Cristal National Park, in the Holguín province in eastern Cuba, to address the need for baseline data on the wildlife of the forest habitats of this biologically important mountain range. This area was chosen because it is known to be a major stronghold of the endemic Cuban solenodon Solenodon cubanus (Insectivora, Solenodontidae). The project initiated and supported field activities of two Cuban institutions involved in nature conservation. The study focused on indicator taxonomic groups. We recorded a total of 220 species of plants, 53 spiders, 28 molluscs, 10 amphibians,
\end{abstract}

19 reptiles, 51 birds, and three species of mammal. The highest number of species were recorded in montane forest. Thirty-five percent of the taxa recorded are endemic to the area or to Cuba. Information gathered during the study will form the basis for developing long-term management plans for habitats and resident species, in conjunction with the authorities responsible for environmental conservation.

Keywords biodiversity assessment, Cuba, endemic species, forest, Sierra del Cristal, Solenodon cubanus.

This article contains supplementary material that can only be found online at http:/ /journals.cambridge.org

\section{Introduction}

Cuba is the largest island $\left(110,922 \mathrm{~km}^{2}\right)$ in the Caribbean, and has the richest biodiversity in the region, with an estimated 6,200 species of flowering plants, 628 vertebrates and 7,500 insects and arachnids (Santana, 1991). The island has also the highest degree of endemism in the West Indies, with c. $50 \%$ of the flora and $32 \%$ of the vertebrate fauna unique to the island (IES/CENBIO, 1998). Approximately two-thirds of the total land area of Cuba is plains (llanuras), and the remainder is foothills and highlands, comprising isolated groups of mountains, the highest of which is the Sierra Maestra in the east (MINAG, 1991). The fertile soil of the lowlands supports extensive sugar

\footnotetext{
J. E. Fa (Corresponding author) Durrell Wildlife Conservation Trust, Les Augrès Manor, Trinity, Jersey, JE3 5BP, Channel Islands, UK. E-mail: jfa@durrell.org
}

J. P. Soy, I. Fernandez and G. Brull Empresa Nacional para la Protección de la Flora y la Fauna, Ministerio de Agricultura, Conill y Avenida Independencia, Havana, Cuba.

\section{R. Capote, A. Avila, F. Cejas, M. Martinez, D. Rodriguez and} A. Rodriguez Instituto de Ecología y Sistematica, Ministerio de Ciencia, Tecnologia y Medio Ambiente, Carretera de Varona, Km 3.5, Boyeros, Havana, Cuba

Received 2 August 2000. Revision requested 1 November 2000. Accepted 26 February 2002 cane, rice and coffee plantations. Most of the island was originally forested, but deforestation since the Spanish conquest and especially after independence, when the lowlands were converted to sugar cane plantations, has left only c. $15 \%$ of the island's original vegetation cover intact.

Since 1959, Cuban institutions have striven for the implementation of effective conservation policies via legislation and creation of protected areas, of which there are currently 236 (CNAP, 2000). However, although advances have been made in documenting biodiversity, some areas, particularly mountainous massifs such as the eastern highlands, are poorly known (IES/CENBIO, 1998).

Together with western Hispaniola, the mountains in eastern Cuba (Sierra Maestra and the Nipe-Sagua-Baracoa range) are remnants of ancient crustal upthrusting and are the most prominent centre of speciation in the Antilles (Garrido \& Jaume, 1984; Schwartz \& Hedges, 1991; Rodriguez Schettino, 1993; Borhidi, 1996). They are also important centres of origin for over 24 Caribbean plant genera, and more than 1,500 plant species are endemic to the eastern Cuban highlands (Capote et al., 1989; Borhidi, 1996). Because of their variable geology, topography and climate, together with anthropogenic effects, these mountains are a mosaic of vegetation types ranging from lowland seasonal rainforest to montane formations (Borhidi, 1996). 
Information from biodiversity inventories and monitoring, and the expertise to analyse these data, are essential for identifying key biodiversity policy and management goals for these regions. In this paper we describe the results of field studies carried out in an area of the Sierra del Cristal, in the Holguín province, by a multidisciplinary team from the Empresa Nacional para la Protección de la Flora y Fauna (ENPFF, Cuba) and the Instituto de Ecología y Sistemática (IES, Cuba), in collaboration with the Durrell Wildlife Conservation Trust (Jersey, UK). The study area was chosen because it is known to be an important stronghold for the endemic Cuban solenodon Solenodon cubanus (Insectivora, Solenodontidae). The ENPFF is the national bureau for nature protection and employs personnel in 46 protected areas throughout the island. The IES is a leading institution, within the Ministry of Science and Technology, dedicated to scientific research on Cuban flora and fauna. The principal aim of the project was to collect baseline biodiversity information within the Sierra del Cristal National Park. We focused on representative taxa, namely plants, spiders, molluscs and vertebrates, that could act as indicators of overall biodiversity (di Castri et al., 1992).

\section{Study area}

Cuba lies within the Neotropical region, just south of the Tropic of Cancer. The climate is tropical with hot summers and mild winters (Núñez Jimenez, 1972). The dry season is in the winter, with 1-2 dry months at the mountain fringes, but with permanently humid rainforest in the interior (Borhidi, 1996). Annual precipitation is 1,600-2,300 mm (Borhidi, 1996). Cyclones are frequent, particularly in September and October. Within the study area, climate is affected by elevation, distance from the ocean and presence of vegetation. Temperatures may be highly variable, from a minimum of $c .9^{\circ} \mathrm{C}$ to a midday maximum of $c .29^{\circ} \mathrm{C}$. Relative humidity is high, ranging from $55 \%$ at midday to $95 \%$ before dawn (Eisenberg \& Gonzalez Gotera, 1985).

Sierra del Cristal forms part of the Nipe-SaguaBaracoa mountain range in eastern Cuba (Fig. 1). This massif consists of deeply inclined conical hills and sharp ridges. The lower sections are covered by ferralitic soils, and by yellowish-red montane clays above $700 \mathrm{~m}$ (Borhidi, 1996). The Sierra is situated between two main river valleys: the Río Mayarí valley in the west and Sagua de Río Tanamo valley in the east. The Sierra is an almost circular massif $c .40 \mathrm{~km}$ across. The only main road into the area is along the north of the Sierra (Núñez Jimenez, 1972).

Sierra del Cristal was the first protected area in Cuba. Through Decreto No.487, the area then known as
El Cristal, Realengo del Cristal or Sierra del Cristal, was declared a National Park on 24 April 1930. Approximately 26,000 ha within the Municipal sectors of Mayarí and Sagua de Tanamo were dedicated to nature protection. However, protection did not become effective until 23 November 1992, when jurisdiction and management of the Sierra were granted to the ENPFF (Resolución No. 454, Ministry of Agriculture). In the 1992 legislation only 15,000 ha were protected from hunting and extraction of natural resources. The park has a buffer zone, but zoning is incomplete. The ENPFF manages the protected area, through staff at the Unidad Territorial de Holguín in Mayarí. The park staff consists of a Chief of Personnel and 15 wardens based within the park.

The Sierra del Cristal region and adjoining areas have been affected by centuries of human occupation and use. Humans have hunted animals, especially hutias (Rodentia, Capromyidae), logged the forests, and extracted a variety of non-timber products. However, there is an elevational limit to human occupation, with no settlements above $400 \mathrm{~m}$. The five main villages in the area (El Culebro, Limoncito, El Palenque, Baconal and La Zanja) are in the foothills of the Sierra (Fig. 1). During the study period, Baconal and El Palenque, which are within the park's buffer zone, had a combined population of 32 people, within eight households. Most of the men were employed by the ENPFF or by the regional agricultural agency (Empresa Municipal Agropecuaria).

Agricultural land is confined to small patches surrounding habitation. Most families cultivate cacao and coffee to sell to state-run industries, and grow root crops such as malanga Xanthosoma sagittifolium (Family Araceae), as well as plantain Musa paradiciaca and cassava Manihot esculenta for their own consumption. About $30 \%$ of the inhabitants raise some pigs and chickens, and a smaller proportion keeps goats. Extraction of timber and non-timber forest products is limited, but fronds from the palms Roystonea regia and Calyptrogyne occidentalis are used extensively for roofing.

According to recent classifications (Capote et al., 1989; Borhidi, 1996) the vegetation of Sierra del Cristal is of four main types: (1) scrub forest, which is a dry and relatively depauperate scrub vegetation typical of areas of serpentine rock; (2) montane forest, which is the climax vegetation type over altitudes of 400-900 m (Borhidi, 1996); (3) evergreen forest, which is a moist forest type associated with lowland areas; and (4) pine forest, which is a formation of endemic pines patchily distributed along the mountainous regions of eastern Cuba.

\section{Methods}

Before the fieldwork commenced we organized a threeday workshop to introduce all team members to the 

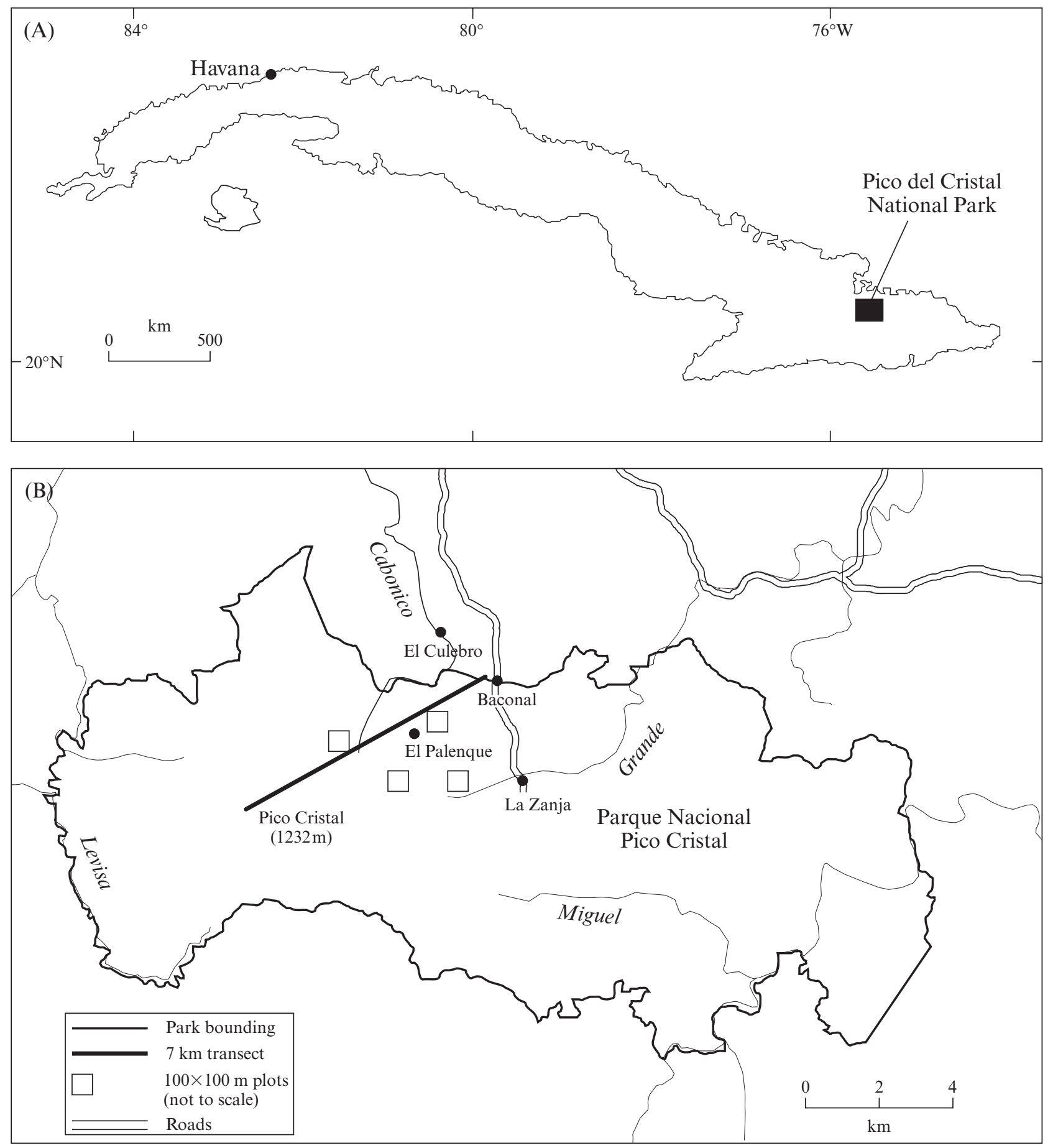

Fig. 1 (A) Cuba, illustrating the location of the Sierra del Cristal National Park, and (B) detail of the study area with localities mentioned in the text, the $7 \mathrm{~km}$ transect and four $100 \times 100 \mathrm{~m}$ plots used for the flora survey, and major rivers.

ecological planning process and field studies. The workshop consisted of instruction and discussion around principles of conservation biology and conservation project management. Aerial photographs were used to identify the main vegetation types within the study area. Fieldwork was undertaken during August-September and November-December 1998, in an area of $48 \mathrm{~km}^{2}$. We undertook habitat inventories, including plant species 
collection and vegetation community analyses, and conducted surveys for the presence of selected animal groups - spiders, molluscs, and terrestrial vertebrates (amphibians, reptiles, birds and mammals) - in three of the four vegetation types (evergreen, montane and scrub forest). The team comprised three botanists, six zoologists and five field assistants.

We set up a $7 \mathrm{~km}$ transect covering the representative habitats of the area, and collected plants at 21 points between 370 and $600 \mathrm{~m}$ altitude (Fig. 1). We also surveyed four $100 \times 100 \mathrm{~m}$ plots to describe the vegetation in more detail.

Spiders were sampled daily throughout the study period using sweep netting and collection of individuals in the tree, shrub and ground vegetation layers. Some sporadic night-time sampling was also carried out. Terrestrial molluscs were sampled daily, from trees, shrubs and ground layers.

Extensive searching for amphibians was undertaken throughout the study area every day and night using standard techniques (Jones, 1986; Heyer et al., 1994). Frogs were located at night by inspecting suitable sites with the aid of flashlights, and by listening to advertisement calls of vocally active species. Microhabitats that are known to be diurnal refuges for anurans, such as epiphytes, fallen logs, loose bark, tree buttresses and rock crevices, were extensively searched during the day. Reptile species were recorded along two line transects $(250 \times 4 \mathrm{~m})$ per habitat, i.e. a total of eight transects. All counts were carried out during 08.00-12.00.

Birds were surveyed using general searching, point counts, and mist netting (Bibby et al., 1992). Sixty point counts were made in total, during the morning or afternoon, at intervals of $100-150 \mathrm{~m}$ along trails in montane, evergreen and scrub forest. On each 10-min count all birds heard or seen were recorded.
Trap-lines for mammals were set within 11 sites in montane forest. In each line 100 Tomahawk single door live traps $(82 \times 23 \times 23 \mathrm{~cm})$ were placed at $10 \mathrm{~m}$ intervals. Tinned sardines were used as bait. Each line was operated for 5-10 nights for a total of 1,477 trap-nights.

\section{Results}

A total of 220 species of plants (Appendix 1), 53 species of spiders (Appendix 2), 28 species of molluscs (Appendix 3), 10 species of amphibians (Appendix 4), 19 species of reptiles (Appendix 5) and 51 species of birds (Appendix 6) was recorded (Table 1). Overall, the greatest number of species was found within montane forest, and the lowest in scrub forest, although there were differences in this respect between the various groups (Table 1). We recorded four bird species (Accipter gunlachii, Amazona leucocephala, Aratinga euops and Myadestes elisabeth) and one mammal (Solenodon cubanus) that were listed as threatened in the 2000 IUCN Red List (Hilton-Taylor, 2000).

Of the vascular plant species recorded $86(39 \%)$ are endemic, $130(59 \%)$ are native species, and two are introduced taxa (1\%) (Appendix 1). Differences between vegetation formations are structural as well as compositional, and plant communities above $600 \mathrm{~m}$ have poorly developed lower canopy and understorey.

Amongst the spiders (Appendix 2), two individuals of the family Hahniidae were discovered, which were new records for Cuba (Avila Calvo, 2000). In both cases only females were found, which made it impossible to identify the species. Amongst the molluscs (Appendix 3), Coryda, Emoda and Veronicella were the most common genera in montane forest, while Subulina, Obeliscus, Coryda and Caracolus were the most common genera in

Table 1 Number of species, endemic species (\%), species in the three vegetation types, and species on the 2000 IUCN Red List (Hilton-Taylor, 2000) recorded in the seven taxonomic groups surveyed in the Sierra del Cristal, Cuba. For further details, see text and Appendices 1-6.

\begin{tabular}{|c|c|c|c|c|c|c|c|}
\hline \multirow[b]{2}{*}{ Taxonomic group } & \multirow[b]{2}{*}{ Appendix } & \multirow{2}{*}{$\begin{array}{l}\text { No. species } \\
\text { recorded }\end{array}$} & \multirow{2}{*}{$\begin{array}{l}\text { No. endemic } \\
\text { species }(\%)\end{array}$} & \multicolumn{3}{|c|}{ No. species in each vegetation type } & \multirow[b]{2}{*}{ No. Red List species } \\
\hline & & & & Evergreen forest & Montane forest & Scrub forest & \\
\hline Vascular plants & 1 & 220 & $86(39)$ & 65 & 134 & 20 & 0 \\
\hline Spiders & 2 & 53 & $4(8)$ & 31 & 18 & 24 & 0 \\
\hline Molluscs & 3 & 28 & $14(50)$ & 20 & 20 & 4 & 0 \\
\hline Amphibians & 4 & 10 & $9(90)$ & 7 & 6 & 0 & 0 \\
\hline Reptiles & 5 & 19 & $11(58)$ & 9 & 15 & 6 & 0 \\
\hline Birds & 6 & 51 & $10(20)$ & 46 & 37 & 15 & 4 \\
\hline Mammals & & 3 & $1(33)$ & 2 & 3 & 2 & 1 \\
\hline Total & & 384 & 135 (35) & 181 & 231 & 72 & 5 \\
\hline
\end{tabular}


evergreen forest. Molluscs were scarce in scrub forest, where only the genera Emoda, Caracolus and Coryda were recorded. The endemic freshwater mollusc Pachylus nigratus was recorded in the Río Cabonico, and a new species of slug Veronicella sp. was discovered in montane forest.

Amongst the amphibians (Appendix 4), an unrecognized species of Eleutherodactylus, possibly a new species of the subgenus Euhyas, was discovered close to human habitation. No evidence was found of the introduced American bullfrog Rana catesbeiana, which is otherwise present throughout Cuba.

We recorded eight species of bird in addition to those reported from the only other bird study in Sierra del Cristal (Abreu et al., 1989). Three endemic genera (Teretistris, Priotelus and Xiphidiopicus) and 10 endemic species were recorded; i.e. $67 \%$ of all Cuban endemic bird species. The most abundant species (Appendix 6) were the Cuban emerald Chlorostilbon ricordii, Cuban bullfinch Melopyrrha nigra, Cuban solitaire Myadestes elisabeth (categorized as Lower Risk, near threatened on the IUCN Red List; Hilton-Taylor, 2000), Oriente warbler Teretistris fornsi, Cuban crow Corvus nasicus and Red-legged thrush Turdus plumbeus. The Cuban parrot Amazona leucocephala, categorized as Lower Risk, near threatened on the IUCN Red List (Hilton-Taylor, 2000), appeared to be common in the area, with flocks of up to 24 individuals observed regularly. The Cuban parakeet Aratinga euops, categorized as Vulnerable on the IUCN Red List (Hilton-Taylor, 2000), was less abundant, with only two flocks, of 17 and 11 individuals, recorded.

Three species of mammals were trapped in montane forest: one Cuban solenodon Solenodon cubanus, 15 black rats Rattus rattus, and one feral cat Felis catus. Rats were active during the daytime and were observed taking the bait from traps without springing them; the number trapped is therefore not representative of the numbers present. Black rats and feral cats were also observed in evergreen and scrub forest.

\section{Discussion}

Although there have been some studies of the wildlife of Sierra del Cristal (Abreu et al., 1989) this is the first detailed biodiversity survey of the area. Our work has indicated that substantial areas of natural habitat still exist in the region, and that within the Eastern Highlands the forest of Sierra del Cristal is important because of both its extent and the relatively low level of human disturbance. The region has been protected for over 70 years and is not currently subject to major pressures of deforestation or wildlife extraction. Our results demonstrated the importance of the area as a reservoir for species that are restricted to montane habitats in Cuba, and for endemic species, which made up $35 \%$ of the total recorded. Amongst the groups surveyed, endemism of molluscs, amphibians and reptiles was particularly high (Table 1).

Together with the Philippines, Cuba is an important global centre of molluscan evolution (de la Torre \& Bartsch, 1938), with 1,405 species so far described, and Cuba has the highest species richness of reptiles in the Caribbean (Estrada \& Ruibal, 1999). Eastern Cuba is a refuge for a number of important mammal species, especially the solenodon (Barbour, 1944; Abreu et al., 1989; Woods \& Eisenberg, 1989), and this species could be used as a flagship species (Entwistle, 2000; BowenJones \& Entwistle, 2002) for furthering conservation efforts in the region. The solenodons are a relict family of primitive insectivores, currently surviving only in Cuba and Hispaniola (MacFadden, 1980). Claims have been made that the species is declining (Varona, 1980) and its range contracting, but this is as yet unconfirmed.

As on many islands throughout the world, the black rat has become firmly established, and its interference was a major problem during trapping for mammals. Black rats have been linked to the extinction or decline of avian and reptile species through predation of eggs nestlings and juveniles, and the rats are potential competitors with ground mammals (Atkinson, 1985).

Local inhabitants confirmed the presence of feral dogs and feral pigs, but we found no direct evidence of either species in the areas that we surveyed. Despite reports that the small Indian mongoose Herpestes javanicus is widespread in Cuba, as on other Caribbean islands (Pimentel, 1955; Nellis \& Everand, 1983), no evidence of its presence was found in Sierra del Cristal, and some residents claim that the species does not occur (Varona, 1983).

We did not survey the bats of the region, but Abreu et al. (1989) reported three bat species, Artibeus jamaicensis, Macrotus waterhousei, and Molossus molossus in the area. Studies of chiropteran diversity need to be undertaken. Abreu et al. (1989) also documented the presence of the hutias Capromys pilorides, C. prehensilis, C. melanurus and C. arboricolous. We found faecal deposits of C. pilorides, and one individual of $C$. melanurus was seen in the evergreen forest. Our lack of success in catching or observing hutias could be an indication of their low numbers. All hutia species in the area have been extensively hunted, especially in the lowland areas.

ENPFF is now carrying out further studies on vegetation ecology in the area, and more detailed research on the fauna. We recommend that further studies of the distribution, abundance and ecology of Red List species, such as the solenodon, are undertaken both within the study area and in other regions of 
eastern Cuba. A full assessment of the Red List status of all species is also required, especially for the endemic species. The potential impact of black rats on birds and the solenodon requires attention and further study. Successful conservation of the biota within the Sierra del Cristal area requires that the National Park guards be supported, and both national and visiting scientists be encouraged to train and mentor students. Information gathered during this study will form the basis for developing long-term management plans for habitats and resident species, in conjunction with the authorities responsible for environmental conservation.

\section{Acknowledgements}

The authors wish to thank the Cuban Ministry of Agriculture and the Ministry of Science, Technology and Environment for permission to work in Sierra del Cristal National Park. The Director of the Empresa Nacional para la Protección de la Flora y Fauna, Comandante de la Revolución Guillermo García, gave encouragement and support to our project. Mr. John Hartley, Director of International Programmes at the Durrell Wildlife Conservation Trust provided support and advice to the project. Mr. Mariano Samada, Head of the ENPFF regional headquarters at Mayarí, provided permits and logistical assistance. We are grateful to Nemecio Perdomo and Joaquin Aldana for help in the field.

\section{References}

Abreu, R.M., de la Cruz, J., Rams, A. \& Garcia, M.E. (1989) Vertebrados del complejo montañoso, La Zoilita. Poeyana, 370, $1-16$

Atkinson, I.A.E. (1985) The spread of commensal species of Rattus to oceanic islands and their effects on island avifaunas. In Conservation of Island Birds: Case Studies for the Management of Threatened Island Species (ed. P.J. Moors), pp. 35-81. ICBP Technical Publication No. 3, Cambridge, UK.

Avila Calvo, A.F. (2000) Primer registro de la familia Hahniidae (Arachnidae: Aranae) para Cuba. Avicennia, 12/13, 135-136.

Barbour, T. (1944) The solenodons of Cuba. Proceedings of the New England Zoological Club, 22, 1-8.

Bibby, C.J., Burgess, N.D. \& Hill, D.A. (1992) Bird Census Techniques. Academic Press, London, UK.

Borhidi, A. (1996) Phytogeography and Vegetation Ecology of Cuba. Akadémiai Kiadó, Budapest, Hungary.

Bowen-Jones, E. \& Entwistle, A. (2002) Identifying appropriate flagship species: the importance of culture and local contexts. Oryx , 36, 189-195.
Capote, R.P., Berazain, R. \& Leiva, A. (1989) Cuba. In Floristic Inventory of Tropical Countries (eds D.G. Campbell \& H.D. Hammond), pp. 317-335. The New York Botanical Garden, New York, USA.

CNAP (2000) Marco Legal, Sistema Nacional de Areas Protegidas, Cuba. MPH Graphics, Havana, Cuba.

de la Torre, C. \& Bartsch, P. (1938) The Cuban operculate land shells of the family Annulariidae, exclusive of the subfamily Chondropominae. Proceedings of the United States National Museum, 85, 193-403.

di Castri, F., Robertson Verbhes, J. \& Younès, T. (1992) Inventorying and Monitoring Biodiversity. Biology International Special Issue no. 27, Oxford, UK.

Eisenberg, J.F. \& Gonzalez Gotera, N. (1985) Observations on the natural history of Solenodon cubanus. Acta Zoologica Fennica, 173, 275-277.

Entwistle, A. (2000) Flagships for the future? Oryx, 34, 239-240

Estrada, A.R. \& Ruibal, R. (1999) A review of Cuban herpetology. In Caribbean Amphibians and Reptiles (ed. B. Crother), pp. 31-62. Academic Press, New York, USA.

Garrido, O.H. \& Jaume, M.L. (1984) Catalogo descriptivo de los anfibios y reptiles de Cuba. Doñana Acta Vertebrata, 11, $1-128$.

Heyer, W.R., Donnelly, M.A., McDiarmid, R.W., Hayek, L.C. \& Foster, M.S. (eds) (1994) Measuring and Monitoring Biological Diversity - Standard Methods for Amphibians. Smithsonian Institution Press, Washington, DC, USA.

Hilton-Taylor, C. (compiler) (2000) 2000 IUCN Red List of Threatened Species. IUCN Gland, Switzerland, and Cambridge, UK.

IES/CENBIO (1998) Estudio sobre la Diversidad Biológica en la República de Cuba. Instituto de Ecología y Sistemática/Centro Nacional de Biodiversidad, Ministerio de Ciencia, Tecnología y Medio Ambiente, Havana, Cuba.

Jones, K.B. (1986) Amphibians and reptiles. In Inventory and Monitoring of Wildlife Habitat (eds A.Y. Cooperrider, R.J. Boyd \& H.R. Stuart), pp. 267-290. US Department of the Interior, Bureau of Land Management, US Government Printing Office, Washington, DC, USA.

MacFadden, B.J. (1980) Rafting mammals or drifting islands? Biogeography of the Greater Antillean insectivores Nesophontes and Solenodon. Journal of Biogeography, 7, 11-22.

MINAG (1991) Plan De Acción Forestal Para Cuba, Documento Base. Ministerio de la Agricultura, Havana, Cuba.

Nellis, D.W. \& Everand, C.O.R. (1983) The Biology of the Mongoose in the Caribbean. Studies of Fauna Curaçao and other Caribbean Islands, Curaçao, West Indies.

Núñez Jiménez, J. (1972) Geografía de Cuba. Editorial Pueblo y Educación, Havana, Cuba.

Pimentel, D. (1955) Biology of the Indian mongoose in Puerto Rico. Journal of Mammalogy, 36, 62-68.

Rodriguez Schettino, L. (1993) Areas faunísticas de Cuba según la distribución ecográfica actual y el endemismo de los reptiles. Poeyana, 6, 1-17.

Santana, E. (1991) Nature conservation and sustainable development in Cuba. Conservation Biology, 5, 13-16.

Schwartz, A. \& Hedges, S.B. (1991) An elevational transect of Lepidoptera on Pico Turquino, Cuba. Caribbean Journal of Science, 27, 130-138. 
Varona, L.S. (1980) Mamiferos de Cuba. Editorial Gente Nueva, Havana, Cuba.

Varona, L.S. (1983) Remarks on the biology and zoogeography of Solenodon (Atopogale) cubanus Peers. 1861 (Mammalia, Insectivora). Birdragen tot de Dierkunde, 53, 93-98.

Woods, C. \& Eisenberg, J.F. (1989) The land mammals of Madagascar and the Greater Antilles: comparison and analysis. In Biogeography of the West Indies: Past, Present and Future (ed. C.A. Woods), pp. 799-826. Sandhill Crane Press, Gainesville, USA.

\section{Appendices 1-6}

The appendices for this article are available online at http://journals.cambridge.org

\section{Biographical sketches}

Dr John E. Fa is Head of the International Training Centre at the Durrell Wildlife Conservation Trust, and is active in research on conservation biology in South and Central America, the Caribbean, Europe and Africa.

Juan Pedro has worked on endangered species and captive breeding programmes within Zoologico Nacional, Havana, for over 20 years. At present he is Head of the Fauna Group of the Empresa Nacional para la Protección de la Flora y la Fauna.

Dr Rene Capote is a member of the Cuban Academy of Sciences and the University of Havana. He is director of national research programmes, and a member of various research councils in Cuba. 


\section{Biodiversity of Sierra del Cristal, Cuba: first insights}

J. E. Fa, J. P. Soy, R. Capote, M. Martínez, I. Fernández, A. Avila, D. Rodríguez, A. Rodríguez, F. Cejas and G. Brull

\section{Appendix 1}

Species of vascular plant recorded in Sierra del Cristal, Cuba.

\begin{tabular}{|c|c|}
\hline Family & Species \\
\hline Acanthaceae & Oplonia sp. \\
\hline \multirow[t]{3}{*}{ Annonaceae } & ${ }^{\mathrm{E}}$ Annona cristalensis \\
\hline & Guatteria blainii \\
\hline & Guatteria sp. \\
\hline \multirow[t]{6}{*}{ Apocynaceae } & Asketanthera fischeri \\
\hline & ${ }^{\mathrm{E}}$ Forsteronia corymbosa \\
\hline & ${ }^{\mathrm{E}}$ Neobracea valenzuelana \\
\hline & ${ }^{\mathrm{E}}$ Plumeria filifolia \\
\hline & Plumeria obtuse \\
\hline & ${ }^{\mathrm{E}}$ Rauvolfia salicifolia \\
\hline \multirow[t]{2}{*}{ Aquifoliaceae } & Ilex macfadyenii \\
\hline & Ilex repanda \\
\hline \multirow[t]{2}{*}{ Araceae } & Philodendron lacerum \\
\hline & Philodendron sp. \\
\hline \multirow[t]{3}{*}{ Araliaceae } & Dendropanax arboreus \\
\hline & ${ }^{\mathrm{E}}$ Dendropanax nervosus \\
\hline & Schefflera morototoni \\
\hline \multirow[t]{3}{*}{ Arecaceae } & ${ }^{\mathrm{E}}$ Bactris cubensis \\
\hline & Calyptronoma sp. \\
\hline & Coccothrinax sp. \\
\hline \multirow[t]{2}{*}{ Asclepiadaceae } & ${ }^{\mathrm{E}}$ Matelea bayatensis \\
\hline & ${ }^{\mathrm{E}}$ Matelea bicolour \\
\hline \multirow[t]{15}{*}{ Asteraceae } & ${ }^{\mathrm{E}}$ Baccharis scoparioides \\
\hline & ${ }^{\mathrm{E}}$ Grisebachianthus lantanifolius \\
\hline & ${ }^{\mathrm{E}}$ Koanophyllon polystictum \\
\hline & Koanophyllon villosum \\
\hline & Mikania sp. \\
\hline & ${ }^{\mathrm{E}}$ Senecio pachylepis \\
\hline & Senecio plumbeus \\
\hline & ${ }^{\mathrm{E}}$ Senecio rivalis \\
\hline & ${ }^{\mathrm{E} S p a n i o p a p p u s ~ h y g r o p h i l u s ~}$ \\
\hline & ${ }^{\mathrm{E}}$ Vernonia aceratoides \\
\hline & ${ }^{\mathrm{E}}$ Vernonia cubensis \\
\hline & ${ }^{\mathrm{E}}$ Vernonia hieracioides \\
\hline & ${ }^{\mathrm{E}}$ Vernonia sagraeana \\
\hline & ${ }^{\mathrm{E}}$ Vernonia segregata \\
\hline & Vernonia sp. \\
\hline \multirow[t]{6}{*}{ Bignoniaceae } & ${ }^{\mathrm{E}} J a c a r a n d a$ arborea \\
\hline & Tabebuia caleticana \\
\hline & ${ }^{\mathrm{E}}$ Tabebuia dubia \\
\hline & ${ }^{\mathrm{E}}$ Tabebuia pachyphylla \\
\hline & ${ }^{\mathrm{E}}$ Tabebuia shaferi \\
\hline & Tabebuia sp. \\
\hline
\end{tabular}

\begin{tabular}{|c|c|}
\hline Family & Species \\
\hline Blechnaceae & Blechnum fragile \\
\hline \multirow[t]{2}{*}{ Boraginaceae } & Cordia sp. \\
\hline & Ehretia tinifolia \\
\hline \multirow[t]{6}{*}{ Bromeliaceae } & Catopsis sp. \\
\hline & ${ }^{\mathrm{E}}$ Pitcairnia cubensis \\
\hline & Tillandsia balbisiana \\
\hline & Tillandsia bulbosa \\
\hline & Tillandsia valenzuelana \\
\hline & Vriesea sp. \\
\hline Buxaceae & ${ }^{\mathrm{E}}$ Buxus marginalis \\
\hline Caesalpiniaceae & ${ }^{\mathrm{E}}$ Senna gundlachii gundlachii \\
\hline Campanulaceae & Lobelia sp. \\
\hline Celastraceae & Torralbasia cuneifolia \\
\hline Chloranthaceae & ${ }^{\mathrm{E}}$ Hedyosmum grisebachii \\
\hline Chrysobalanaceae & Hirtella triandra \\
\hline \multirow[t]{6}{*}{ Clusiaceae } & ${ }^{\mathrm{E}}$ Calophyllum utile \\
\hline & ${ }^{\mathrm{E}}$ Clusia callosa \\
\hline & ${ }^{\mathrm{E} C l u s i a ~ g r i s e b a c h i a n a}$ \\
\hline & Clusia minor \\
\hline & Clusia rosea \\
\hline & ${ }^{\mathrm{E}}$ Gracinia moaensis \\
\hline \multirow[t]{3}{*}{ Combretaceae } & Buchenavia tetraphylla \\
\hline & ${ }^{\mathrm{E}}$ Terminalia orientensis \\
\hline & Terminalia sp. \\
\hline \multirow[t]{2}{*}{ Convolvulaceae } & Ipomoea carolina \\
\hline & Ipomoea sp. \\
\hline \multirow[t]{3}{*}{ Cyatheaceae } & Cnemidaria horrida \\
\hline & Cyathea arborea \\
\hline & Cyathea parvula \\
\hline \multirow[t]{2}{*}{ Cyperaceae } & ${ }^{\mathrm{E}}$ Machaerina cubensis \\
\hline & Rhynchospora pruinosa pruinosa \\
\hline \multirow[t]{3}{*}{ Cyrillaceae } & Cyrilla nipensis \\
\hline & Cyrilla racemiflora \\
\hline & Purdiaea sp. \\
\hline \multirow[t]{2}{*}{ Dennstaedtiaceae } & Odontosoria scandens \\
\hline & Odontosoria sp. \\
\hline Dilleniaceae & Doliocarpus dentatus \\
\hline Dioscoreaceae & Dioscorea sp. \\
\hline Dryopteridaceae & Polystichum echinatum \\
\hline Elaeocarpaceae & Sloanea amygdalina \\
\hline \multirow[t]{3}{*}{ Ericaceae } & ${ }^{\mathrm{E}}$ Lyonia glandulosa var revolutifolia \\
\hline & ${ }^{\mathrm{E}}$ Lyonia myrsinefolia \\
\hline & ${ }^{\mathrm{E}}$ Vaccinium shaferi \\
\hline
\end{tabular}


Appendix 1 continued

\begin{tabular}{|c|c|}
\hline Family & Species \\
\hline Erythroxylaceae & $\begin{array}{l}{ }^{\mathrm{E}} \text { Erythroxylum coriaceum } \\
{ }^{\mathrm{E}} \text { Erythroxylum longipes } \\
\text { Erythroxylum sp. }\end{array}$ \\
\hline Euphobiaceae & $\begin{array}{l}\text { Ditta myricoides } \\
\text { Drypetes serrata } \\
{ }^{\mathrm{E}} \text { Euphorbia helenae helenae } \\
\text { Gymnanthes albicans } \\
{ }^{\mathrm{E}} \text { Hyeronima ovata } \\
{ }^{\mathrm{E}} \text { Leucocroton obovatus } \\
\text { Mettenia acutifolia } \\
{ }^{\mathrm{E}} \text { Moacroton gynopetalus } \\
\text { Moacroton trigonocarpus } \\
\text { Pera ovalifolia } \\
\text { Phyllanthus juglandifolius } \\
\text { juglandifolius } \\
{ }^{\mathrm{E}} \text { Phyllanthus microdictyus } \\
{ }^{\mathrm{E}} \text { Platygyne hexandra } \\
{ }^{\mathrm{E}} \text { Sapium cubense } \\
{ }^{\mathrm{E}} \text { Savia cuneifolia }\end{array}$ \\
\hline Fabaceae & $\begin{array}{l}{ }^{\mathrm{E}} \text { Brya subinermis } \\
\text { Desmodium incanum var } \\
\text { incanum } \\
\text { Teramnus uncinatus }\end{array}$ \\
\hline Flacourtiaceae & $\begin{array}{l}{ }^{\mathrm{E}} \text { Casearia sylvestris var myricoides } \\
{ }^{\mathrm{E}} \text { Lunania cubensis }\end{array}$ \\
\hline Gentianaceae & ${ }^{\mathrm{E}}$ Macrocarpaea pauciflora \\
\hline Gesneriaceae & $\begin{array}{l}{ }^{\mathrm{E}} \text { Gesneria duchartreoides } \\
\text { Gesneria sp. }\end{array}$ \\
\hline Gleicheniaceae & Dicranopteris flexuosa \\
\hline Hymenophyllacea & $\begin{array}{l}\text { Hymenophyllum sp. } \\
\text { Trichomanes scandens }\end{array}$ \\
\hline Lauraceae & $\begin{array}{l}\text { Ocotea foeniculacea } \\
\text { Ocotea leucoxylon } \\
\text { Ocotea nemodaphne }\end{array}$ \\
\hline Liqceae & $\begin{array}{l}\text { Cladonia sp. } \\
\text { Usnea barbata }\end{array}$ \\
\hline Lomariopsidaceae & Elaphoglossum wrightii \\
\hline Lycopodiaceae & Lycopodium sp. \\
\hline Magnoliaceae & ${ }^{\mathrm{E}}$ Talauma minor oblongifolia \\
\hline Malpighiaceae & $\begin{array}{l}{ }^{\mathrm{E}} \text { Byrsonima biflora } \\
\text { Byrsonima coriacea } \\
{ }^{\mathrm{E} B y r s o n i m a} \text { orientensis } \\
\text { Byrsonima sp. } \\
\text { Stigmaphyllon sagraeanum } \\
\text { Triopteris rigida }\end{array}$ \\
\hline Malvaceae & Pavonia fruticosa \\
\hline Marattiaceae & Danaea elliptica \\
\hline Marcgraviaceae & ${ }^{\mathrm{E}}$ Marcgravia evenia \\
\hline Melastomataceae & $\begin{array}{l}\text { Calycogonium sp. } \\
\text { Mecranium purpurascens } \\
\text { Mecranium sp. } \\
{ }^{\mathrm{E}} \text { Miconia baracoensis } \\
\text { Miconia dodecandra } \\
\text { Miconia prasina } \\
\text { Ossaea sp. }\end{array}$ \\
\hline Moraceae & $\begin{array}{l}\text { Cecropia schreberiana } \\
\text { Ficus sp. }\end{array}$ \\
\hline
\end{tabular}

\begin{tabular}{|c|c|}
\hline Family & Species \\
\hline Myrsinaceae & $\begin{array}{l}\text { Myrsine coriacea } \\
\text { Myrsine cubana }\end{array}$ \\
\hline Myrtaceae & $\begin{array}{l}\text { Calycolpus sp. } \\
{ }^{\mathrm{E}} \text { Eugenia scaphophylla }\end{array}$ \\
\hline Nyctaginaceae & Guapira rufescens \\
\hline Ochnaceae & $\begin{array}{l}{ }^{\mathrm{E}} \text { Ouratea revolute } \\
\text { Ouratea striata }\end{array}$ \\
\hline Oleaceae & Chionanthus domingensis \\
\hline Orchidaceae & $\begin{array}{l}\text { Epidendrum jamaicense } \\
\text { Oeceoclades maculata } \\
\text { Phaius tankervilliae } \\
\text { EPleurothallis bovilabia } \\
\text { Polystachya concreta } \\
\text { Vanilla dilloniana } \\
\text { Vanilla wrightii }\end{array}$ \\
\hline Passifloraceae & $\begin{array}{l}\text { Passiflora rubra } \\
\text { Passiflora sp. } \\
\text { Passiflora suberosa } \\
\text { Passiflora tulae }\end{array}$ \\
\hline Piperaceae & $\begin{array}{l}\text { Peperomia guadalupensis } \\
\text { Peperomia hernandiifolia } \\
{ }^{\mathrm{E}} \text { Piper wrightii }\end{array}$ \\
\hline Poaceae & $\begin{array}{l}{ }^{\mathrm{E}} \text { Arthrostylidium fimbriatum } \\
\text { Pharus lappulaceus }\end{array}$ \\
\hline Podocarpaceae & 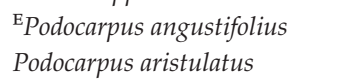 \\
\hline Polygalaceae & Securidaca virgata \\
\hline Polygonaceae & $\begin{array}{l}{ }^{\mathrm{E} C o c c o l o b a} \text { caesia } \\
\text { Coccoloba costata } \\
\text { Coccoloba diversifolia } \\
{ }^{\mathrm{E} C o c c o l o b a} \text { retusa } \\
{ }^{\mathrm{E}} \text { Coccoloba shaferi } \\
\text { Coccoloba sp. }\end{array}$ \\
\hline Polypodiaceae & $\begin{array}{l}\text { Pteridium aquilinum } \\
\text { Thelypteris londiodes }\end{array}$ \\
\hline Rhammnaceae & $\begin{array}{l}{ }^{\mathrm{E}} \text { Colubrina glandulosa nipensis } \\
{ }^{\mathrm{E}} \text { Rhamnidium nipense } \\
{ }^{\mathrm{E}} \text { Rhamnidium shaferi }\end{array}$ \\
\hline Rosaceae & Prunus occidentalis \\
\hline Rubiaceae & $\begin{array}{l}{ }^{\mathrm{E}} \text { Antirhea maestrensis } \\
{ }^{\mathrm{E}} \text { Antirhea scrobiculata } \\
\text { Chiococca alba } \\
{ }^{\mathrm{E}} \text { Chiococca cubensis } \\
\text { Coccocypselum herbaceum } \\
{ }^{\mathrm{E}} \text { Exostema rotundatum } \\
\text { Lasianthus lanceolatus } \\
{ }^{\mathrm{E}} \text { Machaonia microphylla } \\
\text { Psychotria berteroana } \\
\text { Psychotria cuspidate } \\
{ }^{\mathrm{E}} \text { Psychotria ossaeana } \\
\text { Psychotria revolute } \\
\text { Psychotria sp. } \\
\text { Schradera cephalophora } \\
{ }^{\mathrm{E}} \text { Suberanthus canellifolius }\end{array}$ \\
\hline Rutaceae & $\begin{array}{l}{ }^{\mathrm{E}} \text { Helietta glaucenscens } \\
\text { Spathelia sp. } \\
\text { Zanthoxylum sp. }\end{array}$ \\
\hline
\end{tabular}


Appendix 1 continued

\begin{tabular}{ll}
\hline Family & Species \\
\hline Sapindaceae & ${ }^{\mathrm{E}}$ Allophylus cristalensis \\
& Matayba domingensis \\
& Matayba oppositifolia \\
Sapotaceae & Serjania diversifolia \\
& Chrysophyllum sp. \\
& ${ }^{\mathrm{E}}$ Manilkara jaimiqui jaimiqui \\
Schizaeaceae & ${ }^{\mathrm{E}}$ Micropholis polita \\
& ${ }^{\mathrm{E} S \text { Sideroxylon jubilla }}$ \\
Smilacaceae & Anemia coriacea \\
& Lygodium oligostachyum \\
\hline
\end{tabular}

\begin{tabular}{|c|c|}
\hline Family & Species \\
\hline Solanaceae & $\begin{array}{l}\text { Cestrum laurifolium } \\
\text { Solandra sp. } \\
\text { ESolanum moense }\end{array}$ \\
\hline Theaceae & $\begin{array}{l}{ }^{\mathrm{E}} \text { Laplacea cristalensis } \\
{ }^{\mathrm{E}} \text { Laplacea moaensis }\end{array}$ \\
\hline Ulmaceae & Trema micrantha var mollis \\
\hline Verbenaceae & $\begin{array}{l}\text { Callicarpa ferruginea } \\
{ }^{\mathrm{E}} \text { Clerodendrum anafense }\end{array}$ \\
\hline Zingiberaceae & $\begin{array}{l}\text { Clerodendrum sp. } \\
\text { ERenealmia amoena }\end{array}$ \\
\hline
\end{tabular}

${ }^{\mathrm{E}}$ Endemic species

\section{Appendix 2}

Species of spider recorded in Sierra del Cristal, Cuba, with their occurrence in evergreen, montane and scrub forest.

\begin{tabular}{|c|c|c|c|c|}
\hline \multirow[b]{2}{*}{ Family } & \multirow[b]{2}{*}{ Species } & \multicolumn{3}{|l|}{ Habitat type } \\
\hline & & Evergreen forest & Montane forest & Scrub forest \\
\hline Barychelidae & ${ }^{\mathrm{E}}$ Trichopelma cubana & $x$ & & \\
\hline Dipluridae & ${ }^{\mathrm{E}}$ Ischnothele longicauda & $x$ & $\mathrm{x}$ & $x$ \\
\hline Theraphosidae & Citharacanthus sp. & & $\mathrm{x}$ & \\
\hline \multirow{2}{*}{ Anyphaenidae } & Hibana velox & & $x$ & $\mathrm{x}$ \\
\hline & Wulfila longipes & & $x$ & \\
\hline \multirow[t]{3}{*}{ Araneidae } & Araneus pegnia & & $x$ & $x$ \\
\hline & Argiope argentata & $x$ & & $x$ \\
\hline & Cyclosa walckenaeri & $\mathrm{X}$ & $\mathrm{x}$ & \\
\hline \multirow[t]{6}{*}{ Araneidae } & Cyrtophora nympha & $\mathrm{X}$ & $\mathrm{x}$ & \\
\hline & Eriophora ravilla & $x$ & $x$ & \\
\hline & ${ }^{\mathrm{E}}$ Micrathena cubana & & $x$ & \\
\hline & Micrathena horrida & & $x$ & \\
\hline & Micrathena militaris & $x$ & & \\
\hline & Verrucosa arenata & & & $\mathrm{x}$ \\
\hline Clubionidae & Clubiona sp. & & & $x$ \\
\hline Ctenidae & Ctenus vernalis & $\mathrm{X}$ & $x$ & $\mathrm{x}$ \\
\hline Dinopidae & Dinopis lamia & $\mathrm{x}$ & & \\
\hline Gnaphosidae & Unidentified species & & & \\
\hline Hahniidae & Hahnia ernesti? & & & $x$ \\
\hline Heteropodidae & Heteropoda venatoria & $\mathrm{X}$ & & \\
\hline Lycosidae & Lycosa fusca & $x$ & & $x$ \\
\hline Linyphiidae & Frontinella sp. & $\mathrm{x}$ & & \\
\hline Ochyroceratidae & Theotima sp. & $\mathrm{x}$ & & \\
\hline \multirow[t]{2}{*}{ Oonopidae } & Heteronops sp. & $x$ & & \\
\hline & Oonops cubanus & $x$ & & \\
\hline Oxyopidae & Peucetia viridans & & & $X$ \\
\hline \multirow[t]{3}{*}{ Pholcidae } & Bryantina cubana & $X$ & $x$ & \\
\hline & Modisimos sp. & $x$ & $x$ & \\
\hline & Physocyclus globosus & $\mathrm{x}$ & & $x$ \\
\hline Pisauridae & Dolomedes triton & $\mathrm{x}$ & & \\
\hline \multirow[t]{5}{*}{ Salticidae } & Corythalis aurata & $\mathrm{x}$ & $x$ & $x$ \\
\hline & Hentzia antillana & & & $x$ \\
\hline & Lyssomanes antillanus & $\mathrm{x}$ & & $\mathrm{x}$ \\
\hline & Sarinda sp. & & & $x$ \\
\hline & Synemosina smithi & & & $x$ \\
\hline \multirow[t]{3}{*}{ Scytodidae } & Scytodes fusca & & & $\mathrm{x}$ \\
\hline & Scytodes longipes & $\mathrm{x}$ & & \\
\hline & Scytodes sp. & $x$ & & \\
\hline
\end{tabular}


Appendix 2 continued

\begin{tabular}{|c|c|c|c|c|}
\hline \multirow[b]{2}{*}{ Family } & \multirow[b]{2}{*}{ Species } & \multicolumn{3}{|l|}{ Habitat type } \\
\hline & & Evergreen forest & Montane forest & Scrub forest \\
\hline Selenopidae & Selenops aequalis & $\mathrm{X}$ & & $\mathrm{x}$ \\
\hline \multirow[t]{4}{*}{ Tetragnathidae } & Leucauge regny & $\mathrm{x}$ & $\mathrm{x}$ & $x$ \\
\hline & Alcimosphenus licinus & $x$ & & $x$ \\
\hline & Nephila clavipes & & $\mathrm{x}$ & \\
\hline & Tetragnatha elongata & $\mathrm{x}$ & & \\
\hline \multirow[t]{5}{*}{ Theridiidae } & Argyrodes elevatus & & $\mathrm{x}$ & \\
\hline & Argyrodes mexicanus & $\mathrm{x}$ & & \\
\hline & Latrodectus mactans & & & $x$ \\
\hline & Steatoda erigoniformis & & & $\mathrm{X}$ \\
\hline & Theridion rufipes & & & $\mathrm{x}$ \\
\hline \multirow[t]{2}{*}{ Theridiosomatidae } & Wemdilgarda clara & & $x$ & \\
\hline & Misumenops sp. & & & $\mathrm{x}$ \\
\hline Thomisidae & ${ }^{\mathrm{E}}$ Miagrammopes cubanus & $x$ & & \\
\hline \multirow[t]{2}{*}{ Uloboridae } & Philoponella semiplumosa & $\mathrm{x}$ & & \\
\hline & Uloborus glomosus & $\mathrm{X}$ & & \\
\hline
\end{tabular}

${ }^{\mathrm{E}}$ Endemic species

\section{Appendix 3}

Species of terrestrial (with one exception, indicated) mollusc recorded in Sierra del Cristal, Cuba, with the number of localities in which each species was recorded, and their occurrence in evergreen, montane and scrub forest.

\begin{tabular}{|c|c|c|c|c|c|}
\hline \multirow[b]{2}{*}{ Family } & \multirow[b]{2}{*}{ Species } & \multirow[b]{2}{*}{ No. of localities } & \multicolumn{3}{|l|}{ Habitat type } \\
\hline & & & Evergreen forest & Montane forest & Scrub forest \\
\hline \multirow[t]{7}{*}{ Helicinidae } & ${ }^{\mathrm{E}}$ Helicina sp. & 3 & & $X$ & \\
\hline & ${ }^{\mathrm{E}}$ Emoda caledoniensis & 5 & & $X$ & $x$ \\
\hline & Emoda submarginata & 6 & $X$ & $X$ & $X$ \\
\hline & ${ }^{\mathrm{E}}$ Lucidella granullum & 5 & & $X$ & \\
\hline & Alcadia minima & 2 & & $X$ & \\
\hline & ${ }^{\mathrm{E}}$ Alcadia neebiana & 1 & & $X$ & \\
\hline & ${ }^{\mathrm{E}}$ Ceratodiscus sp. & 7 & $x$ & $x$ & \\
\hline Cyclophoridae & ${ }^{\mathrm{E}}$ Crocidopoma sp. & 3 & $X$ & & \\
\hline Annulariidae & ${ }^{\mathrm{E}}$ Chondropoma sp. & 9 & & $X$ & \\
\hline \multirow[t]{2}{*}{ Veronicellidae } & Veronicella cubensis & 8 & $X$ & $X$ & \\
\hline & ${ }^{\mathrm{E}}$ Veronicella sp. & 3 & & $X$ & \\
\hline \multirow[t]{3}{*}{ Helminthoglyptidae } & ${ }^{\mathrm{E}}$ Coryda alauda & 14 & $X$ & $X$ & $X$ \\
\hline & Plagyopticha sp. & 13 & $X$ & $X$ & \\
\hline & ${ }^{\mathrm{E}}$ Cysticopsis sp. & 9 & $X$ & $X$ & \\
\hline \multirow[t]{2}{*}{ Sagdidae } & Hojeda boothiana & 11 & $X$ & $X$ & \\
\hline & Unidentified species & 10 & $X$ & $X$ & \\
\hline \multirow[t]{2}{*}{ Zonitidae } & Hawaiia sp. & 1 & $X$ & & \\
\hline & Guppya gundlachi & 5 & $X$ & $X$ & \\
\hline Pleuroceriidae & Pachychilus nigratus & 1 & $X$ (aquatic) & & \\
\hline \multirow[t]{2}{*}{ Camaenidae } & ${ }^{\mathrm{E} Z a c h r y s i a ~ s p .}$ & 4 & & $X$ & \\
\hline & ${ }^{\mathrm{E}}$ Caracolus sagemon & 9 & $X$ & $X$ & $X$ \\
\hline Succineidae & Succinea sp. & 3 & $X$ & & \\
\hline \multirow[t]{4}{*}{ Subulinidae } & Obeliscus sp. & 15 & $X$ & $X$ & \\
\hline & ${ }^{\mathrm{E}}$ Obeliscus sp. & 4 & $x$ & & \\
\hline & Subulina octona & 4 & $X$ & & \\
\hline & Opeas pumillum & 1 & $X$ & & \\
\hline \multirow[t]{2}{*}{ Oleacinidae } & Oleacina solidula & 8 & $X$ & $X$ & \\
\hline & Oleacina straminea & 1 & $X$ & & \\
\hline
\end{tabular}

${ }^{\mathrm{E}}$ Endemic species 


\section{Appendix 4}

Species of amphibian collected in Sierra del Cristal, Cuba, with the number of individuals found of each species and whether or not vocalizations were recorded.

\begin{tabular}{|c|c|c|c|}
\hline Family & Species & No. of individuals & Vocalizations recorded \\
\hline Hylidae & Osteopillus septentrionalis & 2 & \\
\hline Bufonidae & ${ }^{\mathrm{E}}$ Bufo taladai & 4 & $x$ \\
\hline \multirow[t]{8}{*}{ Leptodactylidae } & ${ }^{\mathrm{E}}$ Eleutherodactylus atkinsi & 16 & $x$ \\
\hline & ${ }^{\mathrm{E}}$ Eleutherodactylus auriculatus & 12 & $x$ \\
\hline & ${ }^{\mathrm{E}}$ Eleutherodactylus dimidiatus & 6 & \\
\hline & ${ }^{\mathrm{E}}$ Eleutherodactylus ionthus & 1 & $x$ \\
\hline & ${ }^{\mathrm{E}}$ Eleutherodactylus cuneatus & 16 & $x$ \\
\hline & ${ }^{\mathrm{E}}$ Eleutherodactylus limbatus & 2 & \\
\hline & ${ }^{\mathrm{E}}$ Eleutherodactylus sp. nov. & 10 & $x$ \\
\hline & ${ }^{\mathrm{E}}$ Eleutherodactylus varleyi & 4 & $x$ \\
\hline
\end{tabular}

${ }^{\mathrm{E}}$ Endemic species

\section{Appendix 5}

Species of reptile collected in Sierra del Cristal, Cuba, with their occurrence in evergreen, montane and scrub forest.

\begin{tabular}{|c|c|c|c|c|}
\hline \multirow[b]{2}{*}{ Family } & \multirow[b]{2}{*}{ Species } & \multicolumn{3}{|l|}{ Habitat type } \\
\hline & & Evergreen forest & Montane forest & Scrub forest \\
\hline Anguidae & ${ }^{\mathrm{E}}$ Diploglossus delasagra & & $x$ & \\
\hline Gekkonidae & Sphaerodactylus celiccelicara & $\mathrm{x}$ & & \\
\hline \multirow[t]{10}{*}{ Polychrotidae } & Anolis angusticeps & & $x$ & \\
\hline & ${ }^{\mathrm{E}}$ Anolis allogus & $x$ & $x$ & \\
\hline & ${ }^{\mathrm{E}}$ Anolis alutaceus & $x$ & $x$ & \\
\hline & ${ }^{\mathrm{E}}$ Anolis argenteolus & $x$ & $x$ & \\
\hline & Anolis homolechis & & & $\mathrm{X}$ \\
\hline & ${ }^{\mathrm{E}}$ Anolis isolepis & & $x$ & $x$ \\
\hline & ${ }^{\mathrm{E}}$ Anolis porcatus & $x$ & $x$ & $x$ \\
\hline & Anolis sagrei & $\mathrm{x}$ & $x$ & $\mathrm{x}$ \\
\hline & ${ }^{\mathrm{E}}$ Anolis sp.nov. (c.f. alutaceus) & & $x$ & \\
\hline & Anolis smallwoodi? & & $x$ & \\
\hline \multirow[t]{2}{*}{ Tropiduridae } & ${ }^{\mathrm{E}}$ Leiocephalus macropus & & $x$ & $x$ \\
\hline & ${ }^{\mathrm{E}}$ Leiocephalus cubensis & $x$ & & \\
\hline Teiidae & Ameiva auberi & & $x$ & $\mathrm{X}$ \\
\hline \multirow[t]{2}{*}{ Colubridae } & Alsophis cantherigerus & & $x$ & \\
\hline & ${ }^{\mathrm{E}}$ Antillophis andreai & $x$ & $x$ & \\
\hline Tropidophidae & ${ }^{\mathrm{E}}$ Tropidophis melanurus & $x$ & & \\
\hline Typhlopsidae & Typhlops lumbricalis & & $\mathrm{x}$ & \\
\hline
\end{tabular}

${ }^{\mathrm{E}}$ Endemic species

(c) $2002 \mathrm{FFI}$, Oryx, 36(4) 


\section{Appendix 6}

Species of bird collected in Sierra del Cristal, Cuba, with their status, and occurrence in evergreen, montane and scrub forest.

\begin{tabular}{|c|c|c|c|c|c|}
\hline \multirow[b]{2}{*}{ Family } & \multirow[b]{2}{*}{ Species } & \multirow[b]{2}{*}{ Status } & \multicolumn{3}{|l|}{ Habitat type } \\
\hline & & & Evergreen forest & Montane forest & Scrub forest \\
\hline \multirow[t]{2}{*}{ Ardeidae } & Bubulcus ibis & S & $x$ & & \\
\hline & Nyctanassa violacea & $\mathrm{C}$ & $\mathrm{x}$ & & \\
\hline Cathartidae & Cathartes aura & C & $x$ & $\mathrm{X}$ & $x$ \\
\hline \multirow[t]{4}{*}{ Accipitridae } & Accipiter striatus & $\mathrm{R}$ & & $x$ & \\
\hline & ${ }^{\mathrm{E}}$ Accipiter gundlachi & C & $\mathrm{X}$ & $\mathrm{X}$ & \\
\hline & Buteo platypterus & & $\mathrm{X}$ & $\mathrm{X}$ & \\
\hline & Buteo jamaicensis & C & $x$ & $x$ & $x$ \\
\hline Falconidae & Falco sparverius & $\mathrm{R}$ & $x$ & & \\
\hline Aramidae & Aramus guarauna & C & $\mathrm{X}$ & & \\
\hline \multirow{4}{*}{ Columbidae } & Columba squamosa & $\mathrm{S}$ & $x$ & $\mathrm{X}$ & $x$ \\
\hline & Zenaida asiatica & C & $x$ & & \\
\hline & Geotrygon caniceps & $\mathrm{R}$ & & $X$ & \\
\hline & Geotrygon montana & $\mathrm{S}$ & $\mathrm{X}$ & $\mathrm{X}$ & \\
\hline \multirow[t]{2}{*}{ Psittacidae } & Amazona leucocephala & $\mathrm{s}$ & $x$ & $x$ & \\
\hline & ${ }^{\mathrm{E}}$ Aratinga euops & S & $x$ & $x$ & \\
\hline \multirow[t]{2}{*}{ Cuculidae } & Saurothera merlini & C & $x$ & $\mathrm{X}$ & $\mathrm{x}$ \\
\hline & Crotophaga ani & C & $\mathrm{x}$ & & \\
\hline \multirow[t]{4}{*}{ Strigidae } & Tyto alba & S & & $X$ & \\
\hline & ${ }^{\mathrm{E}}$ Otus lawrencii & $\mathrm{S}$ & $x$ & $\mathrm{X}$ & \\
\hline & ${ }^{\mathrm{E}}$ Glaucidium siju & C & $x$ & $\mathrm{X}$ & \\
\hline & Asio stygius & $\mathrm{R}$ & $x$ & $x$ & \\
\hline Apodidae & Cypseloides niger & $\mathrm{R}$ & & $\mathrm{X}$ & \\
\hline Trochilidae & Chlorostilbon ricordii & C & $\mathrm{x}$ & $\mathrm{X}$ & $\mathrm{X}$ \\
\hline Trogonidae & ${ }^{\mathrm{E}}$ Priotelus temnurus & C & $\mathrm{X}$ & $\mathrm{X}$ & $\mathrm{X}$ \\
\hline Todidae & ${ }^{\mathrm{E}}$ Todus multicolour & C & $x$ & $x$ & $x$ \\
\hline Alcedinidae & Ceryle alcyon & $\mathrm{R}$ & $\mathrm{x}$ & & \\
\hline \multirow[t]{3}{*}{ Picidae } & Sphyrapicus varius & $\mathrm{s}$ & & $\mathrm{X}$ & \\
\hline & ${ }^{\mathrm{E}}$ Xiphidiopicus percussus & C & $x$ & $x$ & \\
\hline & Colaptes auratus & C & $x$ & $x$ & \\
\hline \multirow[t]{3}{*}{ Tyrannidae } & Contopus caribaea & C & $\mathrm{X}$ & $\mathrm{X}$ & $\mathrm{x}$ \\
\hline & Myiarchus sagrae & $\mathrm{S}$ & $x$ & & \\
\hline & Tyrannus caudifasciatus & C & $\mathrm{X}$ & $\mathrm{X}$ & $x$ \\
\hline Corvidae & Corvus nasicus & C & $x$ & $X$ & \\
\hline \multirow[t]{2}{*}{ Muscicapidae } & ${ }^{\mathrm{E}}$ Myadestes elisabeth & C & $\mathrm{x}$ & $\mathrm{X}$ & \\
\hline & Turdus plumbeus & C & $x$ & $x$ & $x$ \\
\hline \multirow[t]{13}{*}{ Emberizidae } & Parula americana & C & $\mathrm{x}$ & $x$ & \\
\hline & Dendroica tigrina & $\mathrm{S}$ & $\mathrm{X}$ & & \\
\hline & Dendroica caerulescens & C & $x$ & $\mathrm{X}$ & $\mathrm{x}$ \\
\hline & Dendroica dominica & $\mathrm{S}$ & $x$ & & \\
\hline & Mniotilta varia & C & $\mathrm{x}$ & $\mathrm{x}$ & \\
\hline & Setophaga ruticilla & C & $\mathrm{x}$ & $\mathrm{X}$ & $\mathrm{x}$ \\
\hline & Seiurus aurocapillus & $\mathrm{s}$ & $x$ & $\mathrm{x}$ & \\
\hline & Seiurus motacilla & C & $\mathrm{X}$ & $\mathrm{x}$ & \\
\hline & ${ }^{\mathrm{E}}$ Teretistris fornsi & $\mathrm{C}$ & $x$ & $x$ & $x$ \\
\hline & Cyanerpes cyaneus & $\mathrm{R}$ & $x$ & & \\
\hline & Spindalis zena & $\mathrm{R}$ & $x$ & & \\
\hline & Melopyrrha nigra & C & $\mathrm{X}$ & $\mathrm{x}$ & $x$ \\
\hline & Tiaris olivacea & C & $\mathrm{X}$ & $\mathrm{x}$ & $\mathrm{x}$ \\
\hline \multirow{3}{*}{ Icteridae } & ${ }^{\mathrm{E}}$ Dives atroviolacea & C & $x$ & & \\
\hline & Quiscalus niger & C & $x$ & $\mathrm{X}$ & \\
\hline & Icterus dominicensis & C & $\mathrm{X}$ & & \\
\hline
\end{tabular}

${ }^{\mathrm{E}}$ Endemic species

Status: C common, S seasonal migrant, R rare. 